\title{
THE DOCTRINE OF ESTOPPEL APPLIED TO THE STATUTE OF FRAUDS
}

\section{Lionel Morgan Summers}

\section{The Genesis and Development of the Statute}

On April 16, 1677, Charles II, by the Grace of God, King of England, Scotland, Ireland and France, gave his royal assent to three bills, one of which was the famous Statute of Frauds. For several years the Houses of Parliament, guided by the flower of England's jurists, had deliberated over its provisions. In its finished state, the statute was the product of the combined authorship of Lord Guilford, Sir Matthew Hale, Lord Nottingham, Lord North, Sir Leoline Jenkins and a number of lesser celebrities. It was entitled as "An act for prevention of frauds and perjuries" and at its birth it doubtless merited its title. ${ }^{1}$ Without going into particulars as to its scope it may be noted that the statute provided that: I. No interest in lands, except leases not exceeding three years, could be created or surrendered except by writing. II. Signed memoranda were required: (a) to validate promises, of an executor or administrator to answer for damages out of his personal estate, or (b) of a person to pay the debt of another; (c) to enforce fulfillment of contracts made on consideration of marriage, or (d) of executory contracts for the sale of lands; and (e) to enforce performance of contracts that could not be executed within the year. III. Creation or assignment of trusts in land were void unless evidenced by a writing, or were created by operation of law. IV. Contracts for the sale of goods of a greater value than ten pounds were not enforceable unless the contracting parties signed memoranda of the contract

${ }^{2} 29$ Car. II c. 3 (i677). See 8 Pickering, Statutes at Large (1676) 405. Also see Costigan, Date and Authorship of the Statutc of Fratds (1913) 26 HARv. L. REv. 329, and Costigan, Interpretation of the Statute of Frauds (IgIg) I4 IIL L. REv. I for very interesting accounts of its date and authorship. Also Hening, The Original Drafts of the Statute of Frands and Their -4uthors (19I3) 6I U. OF PA. L. REv. 283, where photographic copies of the original statutes are compared with excerpts from the letters of the various authors. (1927) 100 CENT. L. J. I7I has an editorial note on the conclusiveness of Professor Costigan's research on the date of the statute. 
or partly performed it." When passed, the statute consisted of twenty-five sections, but historical development and later statutes have made certain sections, such as the wills provisions, of interest only when studying early cases. ${ }^{3}$ The eight sections summarized above have been re-enacted, with minor modifications, virtually everywhere in the United States.

The purpose of the statute is quite apparent, but it must be remembered that conditions in 1677 were different from those of today. In the first place contract law was in its embryonic stages and but little understood. Trial by jury was even more imperfect than now; there were no rules of evidence to speak of, and parties to the suit were not allowed to testify on their own behalf. ${ }^{4}$ It can readily be seen that, under such circumstances, it was of paramount importance to have written evidence of contracts, else a plaintiff could come into court and have a friend testify to a feigned contract, which a defendant would be powerless to disprove by his own testimony. Also there was a great fear of the uncontrolled power of the juries, accentuated by the decision in Bushell's case. ${ }^{5}$ But it is a far cry from 1677 to 1930 and there is a steadily growing opinion that the statute has outlived its

'For more complete summaries see: SMITH, The LAw of Fratid (1907) 328; 6 HoldSWORTH, HistoRY OF ENGLISH LAW (3d ed. 1924) 384; I WIILISTON, Contracts (Ig20) $\$ 449$.

${ }^{3}$ The Statute of Victcria, known as the Wills Act, 7 WM. IV AND I VICr. c. $26, \S \S 1-3,6-35$ ( 1837 ) superseded the several testamentary provisions of the Statute of Frauds, except in the minority of states that base their respective wills acts on the Statute of Frauds and not on the Statute of Victoria. In the summary (I) equals $\$ \S I, 2,3$; (II) $\S 4$; (III) $\$ \S 7,8,9$; (IV) $\$ 17$. As the trust provisions involve other problems, little will be said about them. In the main, injustice has been prevented by the application of the doctrine of resulting and constructive trusts arising by operation of law, where an express trust would be bad, so that resort to cstoppel is unnecessary. For discussion of the subject see Scott, Conveyances upon Trusts not Properly Declared (1924) 37 HARv. L. Rev. 653; Scott, Resulting Trusts Arising upon the Purchase of Land (1927) 40 Harv. L. Rev. 669; Costigan, Trusts Based on Oral Promises to Hold in Trust, to Convey, or to Devise, Made by Voluntary Grantees (IgI4) I2 MICH. L. REv. 427,515 . Only very occasionally as in the case of Griffin v. Schlenk, $31 \mathrm{Ky} .422$, I02 S. W. 837 (IgO7) is the doctrine of estoppel invoked as well. See note (I922) 22 COL. L. REv. 64.

- Berger, Section Sercnteen in the Light of Two and a Half Centurics (1928) I3 CoRN. L. Q. 303. Also 6 HolnsworTH, op. cit. supra note 2 , at 388.

'I Vaughan I35 (I670); I HoldswoRTH, op. cit. supra note 2, at 344. This case decided that control of the jury by fine or imprisonment was illegal. See also 6 Holdsworth, loc. cit. supra note 4 . 
usefulness and should be repealed. ${ }^{\circ}$ As early as 1885 , Sir Frederick Pollock and Justice Stephens commenting on section seventeen said:

"The special peculiarity of . . . the Statute of Frauds is that it is in the nature of things impossible that it ever should have any operation, except that of enabling a man to escape from the discussion of the question whether he has or has not been guilty of a deliberate fraud by breaking his word." 7

How many unjust suits have been prevented as a result of the statute cannot be estimated, but the reports are filled with cases where just claims have been defeated by its operation. 'This has resulted in a distorting of the statute, in order to prevent injustice, into the most inconceivable meanings, so that cases might be ruled to fall without its provisions. One writer points out that "under the heading of the Statute of Frauds, the Century Digest has digested approximately 6300 cases, the first decennial approximately 2200 and the second decennial approximately 2300 . Of this it is estimated that less than one-third were held to be within the statute." $s$ Worse still, this heterogeneous mass of cases has cost a tremendous sum to litigate, ${ }^{9}$ and even then the decisions are self-contradictory and conflicting. ${ }^{19}$

* “. . the prevailing feeling both in the legal and commercial world is, and has for a long time been, that these clauses have outlived their usefulness, arid are quite out of place amid the changed legal and commercial conditions of today." I HoLDSWORTH, op. cit. supra note 2, at 396. For criticisms of the statute set Sir Frederick Pollock and Justice Stephens, Section Seventeen of the Statute of Frauds (I885) I L. Q. REv. I; Betger, op. cit. supra note 4 ; Burdick, $A$ Statutc for Promoting Frand (1916) 16 CoL. L. Rev. 273; Willis, The Statuste of Friuds-A Legal Anachronism (I928) 3 IND. L. J. 427, 528 . Contra. see Lilienthal, Judicial Repeal of the Statute of Frauds (I8g6) 9 HaRv. L. Rev. 455 ; Betts, Is the Statute of Frcteds Abolished? (I920) 56 CAN. L. J. I6I; Baker, Sales as AfFected by the Statute of Frauds (I887) c. I.

"Pollock and Stephens, op. cit. supra note 6, at 3 . The authors conclude by advising the repeal of the seventeenth section and point out that among the merchants of Liverpool it is tacitly ignored.

${ }^{8}$ Willis, op. cit. supra note 6 , at 537 .

${ }^{9}$ Chancellor Kent put the sum at over $\$ 1,000,000$ in his time.

10 "There is no other statute that has been the source of so much litigation. The elecisions in the same state lack uniformity and are contradictory. The law on the Statute of Frauds is many cases chaotic and unsettled. The statute itself is clear and explicit, seldon requiring construction, but its application is the occasion of the greatest disorder and uncertainty." SMITH, op. cit. supra note 2 , at 327 . Federal Courts do not clarify the situation by laying down a uniform rule because they are bound by the various state interprctations: Interstate Co. v. Bry Block Mercantile Co., 30 F. (2d) I72 (W. D. Tenn. 1928). 
It is quite true that hard cases make bad law, but the converse, that bad law makes hard cases, is equally correct. The statute seems to illustrate the tendency of Anglo-American jurisprudence to enact a law, find it unsatisfactory, for the most part give it lip-service, but in reality either deliberately ignore it or find unwarranted exceptions to it. ${ }^{11}$

\section{Courts of Equity and Courts of Law}

Further complications arise because the statute does not receive the same treatment in the hands of an equity court as it does in the hands of a law court, although it has been repeatedly affirmed that it is as binding on one as on the other. To be sure, both courts allow a quasi-contractual action to recover for benefits conferred under an unenforceable or voidable contract, ${ }^{12}$ but that is done to prevent unjust enrichment and not because of the contract. It is true that the contract may be used in evidence to evaluate benefits but this should not mislead one into thinking that it is enforced, even though a coincidence should make the quasi-contractual recovery exactly the same as recovery on the contract would have been. ${ }^{13}$

Up to the present the law courts have refused to enforce parol contracts within the scope of the Statute of

\footnotetext{
"Speaking of the American Political Mind, Mr. Walter Lippman says: "In legalism it found a tested body of rules from which new rules could be spun without the labor of learning new truths from experience. The formulæ became so curiously sacred that every good foreign observer has been amazed at the contrast between the dynamic practical energy of the American people, and the static theorism of their public life." PuBlic Oprinion 274.

23 The words "unenforceable or voidable" are used with premeditation. The English cases established that parol contracts under the statute were unenforceable and not void, and all the text writers agree that this is the correct interpretation: I W'illiston, op. cit. supra note $2, \$ 527 ; 25$ R. C. L. 692 (19I9). However, Alabama, Colorado, Michigan, Nebraska, Nevada, New Jersey, New York, Oregon, Utah, Wisconsin and Wyoming have complicated the question by inserting the word "void" in their respective statutes. But even then it is questionable if, in view of the historical background, voidable is not really meant. I WILi.ISToN, ibid. \& 53I. Whether a contract is considered unenforceable or voidable is quite immaterial, as the results will be identical. So there is no practical difference between calling a contract unenforceable or voidable. But it must be remembered that a minority of decisions give effect to the word "void" in its full sense.

${ }^{13}$ As to this whole question, see Woodward, The LAw of Quasi Contracts (1913) $144-172$.
} 
Frauds, ${ }^{14}$ whereas equity courts have lent their aid in enforcing such contracts if the elements of fraud, part performance or estoppel were present. In the fraud cases the contract is enforced under the maxim that it is the supreme duty of the courts of equity to prevent fraud, and by enforcing the contract they reach this laudable result. Theoretically, in such cases "relief is afforded in equity becalise of the fraud and not by virtue of the contract". ${ }^{15}$ An even better established basis of relief against the operation of the statute is afforded by the doctrine of part performance. This is not, as has been urged, ${ }^{16}$ in contra-

14 However it is questionable if the application of the doctrine of estoppel to validate contracts unenforcealle under the Statute of Frauds is limited to courts of equity. It is true that in the case of Hayes v. Livingston, 34 Mich. 384 ( 1876 ) a law court refused to recognize such a plea, but that decision was made in 1876 and since then there has been an apparent change in the attitude of the courts. See note $48 \mathrm{~L}$. R. A. (N. S.) 774 (1914) commenting on this transition. See also the case of Hamburger v. Hirsch, 212 S. W. 49 (Mo. App. Igrg). It is possible that a distinction may be drawn between estoppels affecting title to land and those that do not which would reconcile the decision in Hayes $y$. Livingston, supra. See Joy v. Godchaux, 35 F. (2d) 649 (C. C. A. 8th, 1929). The matter is very greatly complicated by the fact that some states following the reformed procedure of New York have merged their courts of law and equity, some while retaining the distinction between their courts have allowed the pleading of equitable defences to legal actions, while still a third group has retained all or virtually all of the old distinctions. In the first group the language of the court in Zellner v. Wassman $c t$ al., I84 Cal. 80, I93 Pac. 84 (Igzo) would seem to imply that no difficulties should arise. They say, at 85 , i93 Pac. at 86: "Where the administration of law and equity has been merged into one court this doctrine of equitable estoppel is not confined to suits it- equity but is equally applicable in an action at law." So, theoretically speaking, it should not matter whether the courts considered estoppel as a legal or as an equitable plea, because it would be given the same consideration under either nomenclature. However, see Clark, The Code Cause of Action (I924) 33 YALE L. J. 817 as to the delusive simplicity of the reformed procedure. In the second class of cases, if the courts consider estoppel as a legal plea there is no difficulty. But if they consider it as equitable, there is difficulty, because estoppel almost invariably in this type of case is not, strictly speaking, a defence, but is pleaded in the replication as a basis for the cause of action. And by the case of. Unicn Pacific Ry. Co. v. Says, 246 Fed. 56I, (C. C. A. 8th, I917) an equitable plea may not be so pleaded. See, as to this, McBaine, Equitable Defences to Actions at Law in the Federal Courts (I929) I7 CALIF. L. REv. 59r. In the jurisdictions of the third class, the plea must be considered as a legal one before it can attain any standing whatever in the law courts. For a classification of the states into the three above-mentioned groups see 2I C. J. (1920) 24. The whole question seems to be in a period of transition, the ultimate result of which will probably be that the plea of estoppel against the Statutc of Frauds will have complete recognition at the hands of a law court. As to the present relations of law and equity, see I Pomeroy, Equity Jurisdiction (4th ed. 19I8) $\$ \S 68-88$.

${ }^{25}$ Wakeman v. Dodd, 27 N. J. Eq. $564(1876)$.

${ }^{16}$ Lilienthal, op. cit. supra note 6. Tennessee, North Carolina, Kentucky, and Mississippi refuse to follow the doctrine. 
vention of the true meaning of the statute, for, as Prof. Costigan points out:

"The statute framers were thoroughly familiar with the part performance problem, and the decisions which shortly after the Statute of Frauds settled the law that part performance would make the oral contract for the sale of land enforceable in chancery, notwithstanding the statute, are conclusive evidence that its framers never intended the statute to prevent the giving of relief in part performance." ${ }^{17}$

In contracts involving land interests it is generally sufficient if the vendee has taken possession of the land in question. ${ }^{18}$ It has been said that "the doctrine of part performance applies exclusively to contracts for the sale of lands". ${ }^{19}$ This is not absolutely true and must be qualified. The dicta of certain courts would seem to show that they recognize part performance as validating other contracts as well. ${ }^{20}$

\section{The Doctrine of Estoppel}

It can readily be seen that equitable relief in cases involving fraud or part performance prevents a great amount of injustice. Nevertheless it is just as obvious that in many cases, where both elements are lacking, a party may, in reliance on the validity of the oral contract, so far change his position that

${ }^{17}$ Costigan, 26 HARv. L. REv. 320, supra note I. There is a fuller discussion of the subject in another connection on page, note 68 infra.

${ }^{18}$ See AmEs, CASES IN EQUITy JURISDICTION (1904) 274-316 for a collection of cases on the subject of equitable enforcement of parol contracts within the Statute of Frauds. Also Browne, STatute of FraUdS (5th ed. I895) 557-621. The utmost that is required to invoke the doctrine of part performance is "pay"ment according to contract, delivery of possession and permanent valuable improvements". Edwards v. Old Settlers Association, I66 S. W. 423 (Tex. I914). By the case of Neale v. Neales, 9 Wall. I (U. S. 1860) it was held that: "Equity protects a parol gift of land equally with a parol agreement to sell it, if accompanied by possession and the donee induced by the promise to give has made valuable improvements on it."

${ }^{10}$ I Wrumston, op. cit. supra note $2, \S 533$.

${ }^{20}$ Seymour v. Oelrichs, 156 Cal. 782, 106 Pac. 88 (1910). The English law on the subject is that "the doctrine of part performance is not confined to those cases which come within the Statute of Frauds because they relate to land, but. on the contrary, extends to every case in which a suit for specific performance of the contract can be maintained and parol evidence is admissible to ground an action where there has been such part performance". 34 IRISH LAw TIMES 330, Aug. II, I900. 
he will suffer great loss if the contract is not enforced against the other contractor. In such cases the invocation of the statute would allow the perpetration of a moral fraud. It cannot be too strongly insisted that there is a difference between this moral fraud and the legal fraud against which a court of equity has always given relief. For the latter there must be an antecedent intent to deceive, perpetrated through the ignorance or gullibility of the victim, or through the false representation to him that a memorandum to satisfy the statute has been made. On the other hand, in moral fraud the person deceiving may never have had an antecedent evil motive. He simply decides that for one reason or another, he will not carry out the contract, despite his prior representations that he would do so. Under such conditions the courts of equity have granted relief under the doctrine of equitable estoppel. Given all the elements of an estoppel in pais, present-day courts of equity will estop a person from setting up the statute where a moral fraud would result thereby. In other words, they will estop him from denying the validity of a contract voidable under the Statute of Frauds. ${ }^{21}$ A little reflection will

${ }^{21}$ The texts on this subject are not very helpful for the simple reason that the latest one, by $S_{M I T H}$, supra note 2, was published in 1907 and the rest were published in the last century. Since then important changes have occurred and a great deal of water has passed under the bridges. Sonce, as 2 REED, THE Statute of Frauds ( 1884 ) 69, limit estoppel to fraud fully made out. Others ignore this question completely: Throop, Validity of Vereal AGreEMENTS (1870) and BaKer, op. cil. supra note 6. AgNew, The Statute of Frauds (1876) limits estoppel to "acts of notoriety not less formal and solemn than the execution of a deed". Brow NE, op. cit. supra note 18 , deals with the question at pages 584-586. The more modern rule is stated in $27 \mathrm{C}$. J. (1922) 338, 20 Cyc. (1902) 308 and to R. C. L. (1915) 833. The subject is touched upon in a few case notes, among them (Ig22) 20 Mich. L. REv. 356 and (I925) 74 U. OF PA. L. REv. I92 dealing with estoppel applied to parol alterations of written contracts within the statute, and (1922) 2 WIS. L. REv. 47 which criticizes the case of Peavey v. Loveland, I74 Wis. 57, I82 N. W. 349 (I921) insisting, probably correctly, that the doctrine of estoppel should not apply if the parties can be put in status quo. The Supreme Court of the United States, commenting on this phase of the law, has said: "Where a person tacitly encourages an act to be done, he cannot afterwards exercise his legal right in opposition to such consent, if his conduct or acts of encouragement induced the other party to change his position so that he will be pecuniarily prejudiced by the assertion of such adversary claim." Swain v. Seamans, 9 Wall. 254, at 274 (U. S. I869). Further cases are cited on later pages with reference to the discussion. There are a few cases contra, but examination will reveal that most of them are cases decided some time ago and are not in harmony with the prevailing authority of today. See Ala Mineral Land Co. v. Jackson, 121 Ala. 172, 25 So. 709 (I8g9); Thompson v. New South Coal Co., I35 Ala. 630, 34 So. 31 (Ig02); Percifield v. Black, I32 Ind. 384. 31 N. E. 955 (I892) ; Brightman v. Hicks, I08 Mass. 246 (I87I); 
show that this is justified by well-established principles. In the first place, the part performance doctrine, long since accepted, in the last analysis, merely works as an extension of the principles of equitable estoppel. ${ }^{22}$ Secondly, by preventing the inequitable use of the Statute of Frauds, the doctrine of estoppel may be an aid in the ultimate function of the statute in preventing fraud. Thirdly, as one court points out: ${ }^{23}$

"The doctrine of estoppel is as old as the Statute of Frauds, and, as such, a part of the law of the land. It is no objection to either, that the one may be a modification or regulation of the other."

Fourthly, courts of equity have always protected a person from the harsh operations of statutes. For instance, a person will not be allowed to set up the Statute of Limitations if he has induced the belief that it would not be invoked. ${ }^{24}$ Especially is this true today. In the past century the courts, influenced by the historical and analytical schools of jurisprudence, became hard and mechanical. This spirit was reflected in the courts of equity with the lamentable result of their losing much, both in influence and in the power of doing good. ${ }^{25}$ So marked was this tendency that Dean Pound, writing at the beginning of this century, entitled

Hayes v. Livingston, supra note I4. Moreover it is possible that some of these cases, although in apparent contradiction, could be justified on the facts. For instance Hayes v. Livingston, supra, is a law and not an equity decision, and if estoppel is considered as an equitable plea the decision is technically correct. The cases may be found collected in $27 \mathrm{C}$. J., supra, and in the 13 THIRD DEC. DiG. (1928) Topic, Frauds, Statute of, Key Nos. I44 and IIg (2).

$=2$ Tiffany, Real Property (2d ed. 1920) 2140 and I20S-1215. In many cases the elcments of part performance and estoppel are both present and it becomes exceedingly hard to determine on which of the glounds the court recided the case.

a Taylor v. Zepp, 44 Mo. 482, 49 I (I85I).

${ }^{3}$ (1928) 37 YALE L. J. 547.

"Dickens in "Bleak House" gives this description of a court of chancery : "This is the Court of Chancery; which has its decaying houses and its blighted lands in every shire; which has its worn out lunatic in every madhouse, and its dead in cvery churchyard; which has its ruined suitor with his slipshod heels and threadbare dress, borrowing and begging through the round of every man's acquaintance; which gives to monied might, the means abundantly of wearing out the right; which so exhausts finances, patience, hope; so overthrows the brain and breaks the heart that there is not an honorable man among its practitioners who would not give-who does not often give-the warning 'Suffer any wrong that can be done you, rather than come here".r 
an article "The Decadence of Equity". ${ }^{26}$ But the analytical and historical schools of the past century have given way to the philosophical and sociological schools of the present and morality has re-asserted itself in the law. ${ }^{27}$ So it is quite in keeping with modern tendencies to avoid too literal interpretations of statutes leading to harsh results.

In connection with this subject, two types of contracts must be considered: primary oral contracts within the statute; and modifications of primary written contracts within the statute. In the latter case, a new contract, a contract to modify, is created. ${ }^{2 s}$ As the problems that arise from reliance on the primary oral contract and on the oral contract to modify are substantially the same, the same principles apply and they shall be discussed together for the most part.

In entering these contracts, the principal reasons that parties may not have fulfilled the statutory requirements are as follows: I. Ignorance by either or both of the parties of the existence of the statute, or that the contract in question fell within its provisions. II. Bona fide belief that a memorandum made to satisfy the statute was sufficient when in reality it is insufficient. III. Reliance on an oral promise to put the oral contract into writing at some subsequent date. ${ }^{29}$ IV. Reliance on a waiver of the defense of the statute.

It has been already stated that present-day courts are practically unanimous in applying estoppel to validate contracts unenforceable under the Statute of Frauds. Though most of the cases that have arisen deal with land contracts, the courts will not limit themselves to these agreements but will apply the doctrine to any

${ }^{26}$ (1905) 5 CoL L. Rev. 20.

${ }^{27}$ If anyone doubts that morality is part of the law, let him read Dean Pound's book LAW AND MORALS (I9I5). Incidentally, a very good discussion of the shift from the analytical and historical methods to those of today is found in this volume.

$\$$ "It then stands as a new agreement, wherein the mutual promises furnish a good consideration", Clark $c t$ al. v. Dales, et al., 20 Barb. 42 , at 64 (N. Y. 1855).

2 As a general rule courts will not allow the enforceneist of the oral promise to put the oral contract into writing, for that would in effect be validating the oral contract. See I WILliston, of. cit. supra note $2, \$ 524$ a. 
contract under the statute. ${ }^{30}$ The crux of the problem presented is to reconcile the decisions of the courts as to what constitutes a sufficient estoppel to take the case out of the statute; many decisions are quite irreconcilable. In some states the courts have admitted the principle, but have been so strict in its application that the doctrine has little practical efficacy. It has been said:

"... the mere fact that one acts on an oral promise hoping that it will be carried out by the promisor does not estop the latter. So as a general rule the mere omission coupled with performance, is insufficient to create an estoppel. The refusal to carry out a promise to put a contract in writing is not such fraud as takes the case out of the statute and this is ordinarily true, even when the party relying simply on the word favor or promise of another has changed his position to his injury on account of it. In all these cases, however, there must be to avoid an estoppel an absence of actual fraud." 31

Besides, if the parties can be put in statu quo, it is doubtful if the courts would apply estoppel. ${ }^{32}$ From this it may be seen that it is of the utmost importance to ascertain the elements of an estoppel. Professor Pomeroy has found that a proper estoppel consists of six elements. ${ }^{33}$

\section{The ELEMENTS OF an EstopPeI}

An examination of the elements separately should prove fruitful. However, the first three are so correlated that they may be considered together:

"I. There must be conduct, acts, language or silence amounting to a representation ${ }^{34}$ or concealment of material

${ }^{30}$ Seymour v. Oelrichs, supra note 20.

${ }^{3}$ Quoted in Little v. Union Oil Co. of California, 23 Cal. App. 612, 621, 238 Pac. 1066, 1069 (1925) giving the rule as stated in I2 CAL. JURISPRUDENCE \$ 104, Statute of Frauds. This is not a statutory change but is merely declaratory of the common law.

${ }^{33}$ See (1922) 2 WIS. L. Rev. 47.

${ }^{\infty} 2$ Ponreroy, op. cit. supra note $14, \$ 805$. However: "It would be unsafe and misleading to rely on the general requisites as applicable to every case without examining the instances in which they have been modified or limited."

${ }^{34}$ Query: Did not Prof. Pomeroy mean misrepresentation? 
facts. II. These facts must be known to the party estopped at the time of his said conduct or at least the circumstances must be such that knowledge of them is necessarily imputed to him. III. The truth concerning these facts must be unknown to the other party claiming benefit of the estoppel at the time when such conduct was done and at the time when it was acted upon by him."

A very clear case that instantly comes to mind is where there is a misrepresentation of certain facts, which if true, would cause the contract to fall without the statute. Thus if $A$ tells $B$ that he will pay $C$ 's debts, and says that he has property belonging to $C$ in his hands, $A$ will be estopped to deny that he has assets of $C^{\prime} s$ with which to pay $C$ 's debts. On such facts the statute will not apply. ${ }^{35}$ Of course, if $A$ intended to mislead $B$, relief should be granted on the ground of fraud, but it is quite conceivable that $A$ was merely careless in supposing that certain assets he possessed were $C$ 's and may never have had any fraudulent intent. ${ }^{36}$

Where both parties are cognizant of the existence of the statute and knowingly waive its benefit a true estoppel is created, for it comes within the well established exception that waiver of an existing right on which waiver another party relies gives rise to an estoppel. The "existing right" is the right to have the contract put into writing before it can be considered binding. ${ }^{37}$ It does not matter whether the contract is considered void, voidable

$\approx$ Dock v. Boyd \& Co., 93 Pa. 92 (I880).

${ }^{36}$ Likewise a person is estopped to deny the authority of his agent whose appointment was invalid under the Statute of Frauds: Karns v. Oiney, 80 Cal. 90, 22 Pac. 57 (I889) ; Brenneman v. Lane, 87 Cal. App. 4I4, 262 Pac. 400 (1927).

37 "Contracts within the Statute of Frauds are not void but only voidable at the election of the party to be charged. He may waive the necessity of the writing required by the statute and thereby make the contract binding." St. Louis $\mathrm{K}$ and N. W. Ry. Co. v. Clark, I2I Mo. I69, I86, 25 S. W. I92, I96 (I893), 26 L. R. A. 75I (I894). Also "A plaintiff . . . must be able to show clearly such acts and conduct of the defendant as the court would hold to amount to a representation that he proposed to stand by his agreement and not avail himself of the statute to escape his performance and also that the plaintiff in reliance on this representation proceeded either in performance or pursuance of his contract, to so far alter his position as to incur an unjust and unconscientious injury and loss in case the defendant is permitted after all to rely upon the statutory defence." BRownE, op. cit. supra note $2 \mathrm{I}$, at 585, quoted with approval in Zellner v. Wassman et al., supra note 14 , at 87,193 Pac. at 87. 
or unenforceable for the right that is waived is the same under any one of the three views. ${ }^{38}$

A more difficult problem arises where there has been a parol modification of a written contract within the Statute of Frauds. As has been shown a new contract is created, but it is likely that in its creation a right under the existing contract has been modified or abandoned. If this modification or abandonment is relied upon it would be highly inequitable to permit the setting up of the statute to invalidate the second contract. ${ }^{39}$ Thus an example would be where $B$ grants $A$ a parol extension of a lease during which $A$ may give notice to terminate. $A$ relies on this waiver of an existing right, $i$. e., to have notice of termination within a certain day, and thereafter $B$ is estopped to deny the validity of the new contract granting the extension. ${ }^{40}$

But there may be another type of case in which none, or virtually none, of the rights under the old contract is abandoned. the parol modification calling instead for further performance of a positive nature. In that case the waiver of an existing right theory should not apply and if an estoppel be pleaded, it should be supported, if supported at all, on other grounds.

There seems to be no reason why estoppel should not be applied where the party to be estopped knew of the existence of the

\footnotetext{
${ }^{33}$ However, see note (1906) Ig HARV. L. Rev. 455 where, in a discussion of the effects of estoppel on void contracts, the author says: "As a general rulc there seems to be no gond reason for allowing estoppel to make valid a void contract." The cases of Ala. Mineral Land Co. v. Jackson, and Thompson v. New South Coal Co., both supra 2I, and note 62 L. R. A. 55I (1903) are in accord with this statement. They refuse to apply estoppel on the ground that as the contract was void in its literal sense, there was a mere nullity on which an estoppel could not operate. But there is such an overwhelming number of cases holding the other way which allow estoppel to operate on contracts considered void, that this position is hardly tenable. See for instance, the case of Dobbs v. Atlas Elevator Co., 25 S. D. 177, 126 N. W. 250 (1910).

sa "Where a representation as to the future relates to an intended abandonment of an existing right and is made to influence others and they have been infuenced by it to act, it operates as an estoppel." Kingston v. Walters, I6 N. Mr. 59, 64, II3 Pac. 594, 595 (I9I1). See also Daniels v. Rogers et al., roS App. Div. 338, 96 N. Y. Supp. 642 (1905) ; Scott v. Hubbard, 67 Ore. 498 , 136 Pac. 653 (I9r3); Rogers v. Maloney, 85 Ore. 61, I65 Pac. 357 (I917). There is an annotation to Kingsley v. Kressly, 60 Ore. 167, 118 Pac. 678 (I9II) in ANN. Cas. I9I3 E 746, which deals with this type of case.

${ }^{10}$ Hamburger v. Hirsch et al., supra note 14 .
} 
statute and the other party did not. ${ }^{41}$ Certainly it is most unconscientious for one person deliberately to take advantage of the ignorance of another by inducing him to enter into a contract which he knows full well is not enforceable against himself. The misrepresentation of "fact" is then the implied statement that the contract was binding when in reality it was not. Of course this is really a misrepresentation of law and not of fact but since the celebrated case of Storrs $v$. Barker, ${ }^{42}$ misrepresentations of law have also given rise to estoppels.

It cannot be questioned that legal fraud creates an estoppel against the Statute of Frauds. On theory this would seem rather needless as fraud in itself is a sufficient reply against the plea of the statute without resort to estoppel, but practically it does no harm. ${ }^{43}$

While there may be other cases and examples not covered in the above classification, those enumerated embrace, in the main, that class of cases where there is little doubt that if an estoppel be properly pleaded ${ }^{44}$ and the other elements are present, the

4 Though the following statement was not made about the Statute of Frauds it is nevertheless apropos: "It is generally stated as the settled rule that estoppel cannot be found upon a misrepresentation of law. . . The basis of this rule is that everyone is presumed to know the law, or that statement of the law can only be an opinion. However, an exception to the rule is recognized when the person making the statement is in a particularly good position to know the law. A fortiori, a further exception to the general rule seerns proper, where, as in this case the misrepresentation by a person who knows the law is made to a person clearly not knowing the law. A statement of law should not be called an opinion when made and acted upon as a fact." (IgI7) 3I HaRv. L. Rev. 655 .

6 Johns. 166 (N. Y. I822).

48 Hedges \& Co. v. Howard, 5 R. I. I49 ( 1858 ) ; Bigesow, Estopper (6th ed. 1913) 782: "Indeed the ground upon which equity treats the case as out of the Statute of Frauds, to wit, the fraud of the person to be estopped should be sufficient to justify a court of law in acting. The ground of an estoppel by conduct commonly is fraud and it cannot be that a statute made to prevent the accomplishment of fraud should stand in the way, preventing such a result in any court." Ordinarily legal fraud is not necessary to create an estoppel. In the case of Anderson v. Hubble, 93 Ind. 570, at 577 (1883) it was said: "All that is meant in the expression that an estoppel must possess an element of fraud is that the case must be one in which the circumstances and conduct would render it a fraud for the party to deny what he had previously induced or suffered another to take action upon. . . There need be no precedent corrupt motive or evil design."

"The court in Rheingars v. Smith, I6I Cal. 362 at 366, II Pac. 494, at 496 (I9II) said: "It has occurred to the court that defendant might be estopped to i.ssert rights under his contract upon the principles stated in Seymour v. Oelrichs." But as the other party did not urge it, the court did not interpose on their own initiative. Seymour v. Oelrichs, supra note 20 , is discussed in the folInwing parag raph. 
court will uphold the plea, and be satisfied that it is perfectly consistent with established legal principles. It has seemed unnecessary to dwell on elements II and III because it is obvious beyond need of discussion that the fact, the intent to abide by the waiver, and the fraudulent intent were or should have been known to the party against whom the estoppel operates, and were unknown to the one setting it up.

A very important question, as to the applicability of estoppel, that must be treated by itself arises where one person has relied on the promise of another to put the contract into writing at some subsequent date. If the promise was made with the intent of influencing the other contracting party, the case falls within the principles of Seymour $v$. Oelrichs, ${ }^{45}$ an able decision of the California Supreme Court. In that case, plaintiff was captain on the police force, assured of a life position at \$250 a month. Defendants, through their agents, urged him to accept a position as manager of their estates at $\$ 300$ a month for a period of ten years. He was urged to resign his position and begin work at once and was told that the contract would be put into writing at a convenient later date. Accordingingly he did resign and commenced his employment, but after two years defendants repudiated the contract. The court held that they were estopped to deny its existence. In its decision the court admitted that it was difficult to say a material fact was misrepresented; but to show that such a statement could be made, quoted from Prof. Pomeroy:

"A representation of a future intention, absolute in form, deliberately made for the purpose of influencing the conduct of the other party and then acted upon by him, is generally the source of a right and may amount to a contract enforceable as such by a court of equity." 46

There can be no quarrel with the eminent justice of this decision, but it must be confessed that it is not universally followed. ${ }^{47}$

¿S Supra note 20.

" 2 POMEROY, op. cit. supra note I4, \&877 n.

${ }^{17}$ See Nehls et al. v. Williams Stock Farming Co., 43 Nev. 253, I84 Pac. 212 (1919) ; reaff'd: i85 Pac. 563 (I9I9), where the Nevada Court declined to say whether it would have followed Seymour v. Oelrichs, supra note 20, if the facts had been the same. 
However, it might have been better had the court called it a promissory estoppel because at bottom the fact is not there. ${ }^{4 s}$ It is true that promissory estoppels have been recognized somewhat diffidently and then mostly in the cases of charitable subscriptions where consideration is lacking, ${ }^{49}$ but that is no reason why this principle should not be extended to promote justice in just such a case as this. Certainly it is in accord with what Dean Pound has described as "the perennial movement in the law toward a fuller and wider securing of interests and hence towards a wider and fuller enforcement of promises". ${ }^{50}$

The next question presents a very labyrinth of problems. There are many cases where parties materially change their position on the mistaken assumption that the unenforceable contract was binding which assumption was induced either by the ignorance of the existence of the statute, a mistaken belief that it did not apply, or else through a misapprehension as to what memorandum was required. Relief has been given on the grounds of estoppel in numerous decisions. ${ }^{51}$ Other courts have denied relief on the ground that at most it is an oral promise. ${ }^{52}$ The court in Dechenbach v. Rima ${ }^{\overline{5} 3}$ quotes the following statement:

${ }^{4}$ Especially as the quotation from Pomeroy is taken from a chapter on fraud and the court had specifically denied the existence of any fraud.

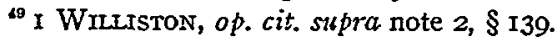

${ }^{50}$ Pound, Consideration in Equity (I9I8) I3 ILL. L. Rev. 667, at 679.

a Ala. G. S. R. R. Co. v. S. and N. Ala. R. R. Co., 84 Ala. 570 (1887); Price v. Thompson, 4 Ga. App. 46, 60 S. E. 800 (Ig08) ; Cross v. Weare Commission Co., I53 Ill. 499, 38 N. E. 1038 (I894); Hartz et al. v. Kales Realty Co., 178 Mich. $560,146 \mathrm{~N}$. W. I60 (I914); Thompson v. Hurson et al., 201 Mich. 685,167 N. W. 926 (1918); Munsch v. Stetler, 109 Minn. 403, 124 N. W. I4 (Igro); Delta Lumber Co. v. Wall, I I9 Miss. 350, 80 So. 782 (I9I9); Taylor v. Zepp, supra note 23; Dwight et al. v. Williams et al., 25 Misc. 667, $55 \mathrm{~N}$. Y. Supp. 201 (18g8); First National Bank v. LaFayette Trust Co., 85 Misc. 34I, 148 N. Y. Supp. 49I (I9I4) ; Dobbs v. Atlas Elevator Co., 25 S. D. 177, 126 N. W. 250 (I9I0) ; Hand v. Nix et $34 x ., 39$ Tex. Civ. App. 403, 87 S. W. 204 (I905); O'Connor et ux. v. Oliver et al., 45 Wash. 549, 88 Pac. ro25 (I907); Tufts v. Copen, 37 W. Va. 623 , I6 S. E. 793 (1893). However it must be confessed that some of these cases may belong in the "waiver of the benefit of the statute" or other categories. As a general rule estoppel is applied witlout much discussion as to what elements are present so that classifying the cases is not always easy.

${ }^{62}$ Miller v. Hart, I22 Ky. 494, 9I S. W. 698 (1006) ; Nehls et al. v. Willians Stock Farming Co., supra note 47 ; Robbins v. Winters et al., 203 S. W. 149 (Mo. App. 1918).

${ }^{3} 45$ Ore. 500, 506, 78 Pac. 666, 668 (1904). 
"That a party was ignorant of the law, or that he confided in the promise of another, and acted upon it to his disadvantage, has never been held to be an answer to the statute."

If it is admitted that there can never be an estoppel unless every element is present, there is no question that Dechenbach v. Rima reaches a substantially correct result, because one of the elements, namely the third, is missing. ${ }^{54}$ The misrepresented fact, or in this case law, is supplied by the implied statement that the contract is legally binding when in reality it is not. As ignorance of the law is not deemed an excuse, the person estopped must admit that knowledge of the law is necessarily imputed to him. ${ }^{55}$ But the same is true of the person setting up the estoppel so that he cannot claim that he was acting in ignorance of the true state of the law. In those cases already mentioned where a misrepresentation of law has given rise to an estoppel it has been a misrepresentation of law operating on particular facts and not a misrepresentation of the general scope of law or of a law. So it would be erroneous to say that Storrs v. Barker and analogous decisions are precedents for the Statute of Frauds cases. ${ }^{56}$ Nor can it be said that, as neither party can plead ignorance of the law, if they continued with the contract an implied waiver of the Statute of Frauds exists, because a waiver can apply only to known rights.

But under such reasoning a person is able to set up the Statute of Frauds as a mere excuse for not performing a contract which at one time he himself was quite willing to perform. The

at "The truth concerning these facts must be unknown to the other party claiming benefit of the estoppel at the time when such conduct was done and at the time when it was acted upon by him." 2 Pomeroy, op. cit. supra note If, $\$ 805$.

${ }^{\star}$ This theory that ignorance of the law excuses no one originated with Lord Ellenborough in the case of Bilbie v. Lumley, 2 East $469,470,472$ (1802). Often it leads to most unfortunate results, but as it seems to be so firmly entrenched in our jurisprudence we must accept it whether we like it or not. See, however, WOODWARD, op. cit. supra note 13, ch. III where this question is discussed in conjunction with the quasi contractual problem of recovering money paid under a mistake of law. See also note $4 \mathrm{I}$ supra.

${ }^{6}$ The facts of Storrs v. Barker, supra note 42, are as follows: Defendant, ignorant of the fact (law) that his daughter, as feme covert, could not devise, encouraged another to buy land from the devisee. Later he found out that he was the heir. Held, that he was estopped to set up his title. See also note 48 , L. R. A. (N. s.) 773 (1914). 
result is often a great loss and hardship on the other contractor who has changed his position in reliance on the validity of the oral contract. ${ }^{57}$ To prevent this from occurring, the plea of estoppel is here often allowed, despite the absence of the third element, or, disregarding the fiction of the presumed knowledge of the law, the second element. Sometimes the Gordian knot is cut by failing to discuss the misrepresented fact, in some instances by claiming that it would be fraud to set up the statute after having led another to rely on the contract. ${ }^{58}$ It needs no extended comment to show that in such cases the courts confuse moral fraud with legal fraud. It is debatable as to whether it would not be better if the courts, instead of trying to justify their decisions under this incomplete estoppel, might not frankly grant relief on the grounds of hardship. ${ }^{59}$ If it were anything but estoppel, that would be a very cogent argument, but estoppel is a constantly expanding doctrine and, as Prof. Pomeroy warns:

"It would be unsafe and misleading to rely on these general requisites as applicable in every case without examining the instances in which they have been modified or limited." 80

Moreover the granting of estoppel in these cases does not seem to do violence to the broad definition of this principle given by Prof. Pomeroy:

"Equitable estoppel is the effect of the voluntary conduct of a party whereby he is absolutely precluded both at law and in equity from asserting rights which might have existed either of property, of contract or of remedy, as against

m The mischievous result of enforcing the statute strictly is seen in the case of Sievewright v. Archibald, I7 Q. B. 118, at II9 (1886), where Campbell, C. J., said: "I regret to say that the view which I take of the law in this case compels me to come to the conclusion that the defendant is entitled to our judgment, although the merits are entirely against him; although believing that he had broken the contract, he could only have defended his action in the hope of mitigating the damages; and although he was not aware of the objection on which he now relies, till within a few days before the trial."

${ }^{6}$ See Glass v. Hulbert, 102 Mass. 24, at 35 (1869) for probably the most widely quoted paragraph in this field of law.

so Ordinarily hardship of itself does not take a case out of the statute. See note (I924) 2 TEX. L. REv. 347. See also the early case of Hollis v. Whiteing, I Vern. I5I (I682).

${ }^{\infty}$ See supra note 33 . 
another person, who has in good faith relied upon such conduct, and has changed his position for the worse, and who on his part acquires some corresponding right either of property, of contract or of remedy." 61

Though Dean Pound calls estoppel "that much enduring word", 6: at another time in lamenting the decadence of equity, he cites estoppel as a conspicuous example of an equitable principle acquiring a legal shell so that "we now regard precedent as at least of equal weight with the equities of the case in question". ${ }^{63}$ Can it not be said that there is a revival of the old idea in these cases? Especially as in a recent case ${ }^{64}$ the following remarks on estoppel are quoted with approval:

"It is a growing branch of the law, in which decided cases are of less value than usual, for the reason that every cause must depend upon its peculiar facts and circumstances."

Casting about for analogies, the closest that can be found is the case of a corporation estopped to deny the validity of an ultra vires act even though the other person had constructive notice of the corporation's charter. In Harris $v$. Gas Co., ${ }^{65}$ the following: comment is made:

"These cases have been criticized for the use they make of the word 'estoppel' as descriptive of the principle upon which they are based. It is argued that as a corporation must know the terms of its own charter and as one dealing with it must be charged with a like knowledge, neither party to an ultra vires contract can be misled in that respect and therefore there must always be lacking an essential element of what could with technical accuracy be called an estoppel. This, however, is a mere question of terminology. The re-

22 Ponreroy, op. cit. suspra note $14, \S 804$. For other good definitions of estoppel see Bouvier's Law Dictionary, quoting the United States Supreme Court in Dickerson v. Colgrove, 100 U. S. 578 at 580 (I879). Note (IgI5) 28 HARv. I. REv. 4I5 at 423 et seq. carries a short and valuable discussion of estoppel in pais. The leading treatises on the subject are those of Bigelow, op. cit. supra note 43, and EwarT, Estopper (1900). There are also treatises by Caspersz, Chand, Herman and Van Fleet.

${ }^{a}$ Pound, The Progress of the Law (1920) 33 HARv. L. REv. 929, at 942.

${ }^{e}$ Pound, op. cit. supra note 26 , at 33 .

es Interstate Co. v. Bry Block Manufacturing Co., supra note to.

${ }^{\infty} 76$ Kan. 750, 753, 92 Pac. I123, I124 (1907). 
quirement that one shall be consistent in conduct-shall not occupy contradictory positions-shall not retain the advantages of a transaction and reject its burdens-is often spoken of as a form of estoppel. The term is convenient, and if inaccurate is not misleading. This rule of estoppel affords a good working hypothesis to accomplish just results."

Precisely the same reasoning is applicable to the cases under discussion, so that the use of the word estoppel is not as blameworthy as it may at first appear.

At this point it may be urged that only the very clearest cases of estoppel should be allowed to overthrow the express letter of the law, and that by extending the principles of equitable estoppel beyond its strict bounds the courts are indulging in judicial legislation. But applying the usual rules of statutory construction and looking at the intent of Parliament and the evils that the statute was supposed to remedy it seems that this argument must be answered in the negative. To begin with there can be but little doubt that the statute was passed primarily to curb the power of the juries. Prof. Costigan even argues that it never was intended to apply to Chancery and that Chancery accepted it merely because it wished to follow the law. ${ }^{66}$ Yet Dean Pound's criticism of this argument seems valid, namely, that if it had not been intended to apply to equity they should have spoken thus :

"Since with our modes of proof we can obviate the mischiefs of seventeenth century jury trial, for which alone the statute was devised we will specifically enforce all contracts written or oral according to the general principles of our jurisprudence." 67

But had that been the case it is conceivable that suit after suit would have been brought in Chancery on the pretext that the legal remedy was inadequate, and a large part of the jurisdiction of the common law courts would have been cut off. Neither could equity discard the Statute of Frauds as it did the Statute of Limitations for, in the latter case, equity had always enforced the

${ }^{\infty}$ Costigan, Has There Been Judicial Legislation in the Interpretation and Application of the "Upon Consideration of Marriage" and Other Contract Clauses of the Statute of Frauds (I9r9) I4 IrI. L. REV. I.

or Pound, op. cit. supra note 62 , at 936 . 
analogous doctrine of laches while there was nothing in equity similar to the Statute of Frauds. So what Chancery did was to accept the statute and proceed to engraft exceptions to it; part performance because transfer of possession had in it the elements of a common law conveyance, $i$. e., livery of seisin ${ }^{68}$ and relief from fraud on the ground that a statute enacted to prevent fraud should not be used as an instrument of fraud. This was not anomalous, inasmuch as the same judges that interpreted the statute had drafted it, and consequently they were merely interpreting it as it was meant to be interpreted. In other cases as well, the court of Chancery, directly after the passage of the statute, tried to restrict its operation wherever it could. ${ }^{69}$ Of course, later on, harsher decisions were made, precedents crystallized and the original purport of the statute was lost sight of. But of recent years equitable principles have taken on a new lease of life and the rigidity of the nineteenth century decisions has been relaxed, ${ }^{7 n}$ so that these decisions are not necessarily authority today. Thus, when it is contemplated that the statute is a seventeenth century statute, and the chief reasons for its enactment are gone, the courts are justified in going even further than the early courts, by extending the plea of estoppel to cases where one of the elements is lacking. As Prof. Costigan points out:

"Since the need of the statute is less today the court, in a doubtful case, may well restrict the operation of the statute wherever reasonably possible." 71

And it is very doubtful indeed if it was ever intended that the statute should work rank injustice.

Objection will at once be made that this is destroying the wholesome defence of the statute and opening the way to fraud. To begin with, it is almost inconceivable that anyone should materially change his position, so as to satisfy all the elements

Co The unequivocal act explanation came later and was fully expounded by the Earl of Selborn in Maddison v. Alderson, L. R. 8 App. Cas. 467 (1883).

${ }^{\omega}$ Sce 2I Eng. Reprints 84I (Ig02), where the cases on the Statute of Frauds decided up to 1744 are abridged and collected. page

to This liberalizing tendency of today has already been discussed supro ${ }^{2}$ Costigan, op. cit. supra note 66 , at 37 . 
of an estoppel, on the expectation of recouping himself on a "framed" contract. Secondly, there is a very serious doubt as to what protection the statute really does afford. Despite the lofty words about its glory that are so often pronounced, its protection, in most cases, is more illusory than real. If a clever scoundrel does want to "frame" a contract all he has to do is to frame one without the statute, which is not very hard to do considering the numerous exceptions to it. Only in the cases of land contracts will he be balked, and even then if he is really clever, he may surmount this difficulty by alleging a writing and its subsequent loss. ${ }^{72}$

The many problems revolving around the "fact" element and its fundamental importance have made it necessary to dwell on this phase of the subject. Proceeding with the discussion of the remaining elements, the next in order is the fourth:

"The conduct must be done with the intention or at least with the expectation that it will be acted upon by the other party. There are several familiar species in which it is simply impossible to ascribe any intention or even expectation to the party estopped, so that his conduct will be acted upon by the one who afterwards claims the benefit of the estoppel."

However, the Statute of Frauds cases do not fall within these species for the contract must be represented as binding with the clear expectation that the other party shall change his position as a result. For instance: $A$ had a contract to carry mail for the government for a period of four years. $B$ sub-contracted to carry it for the remaining time, over one year, and promised to make a written contract to that effect. $B$ then refused to do so. In the meantime $A$, relying on the oral contract had left Susanville, where he had been operating and sold his horses and rig. But as $B$ had never known that $A$ was acting in reliance on the contract and not from other reasons, $B$ was not estopped to deny the contract, even though $A$ suffered considerable damage, through

${ }^{72}$ On the subject of lost instruments see: Jones, Evidence (3d ed. I924) $\$ 214$ and $n .96$ for examples; 4 WIGMORE, EVIDENCE (2d ed. I923) \$2IO5 b; MCKEIVEY, EvIDENCE (3d ed. I924) §283; I REED, op. cit. supra note 21, §326 and 3 ibid. \& 1100 . 
having to re-settle in Susanville and re-equip himself. ${ }^{73}$ Another federal court refused to recognize an estoppel (though fully recognizing the principle ${ }^{74}$ ) under these facts: $B$, relying on an oral sale transacted with $S$, resold the goods which he thought he had purchased to $X$, so as to subject himself to liability to $X$ if $S$ did not consummate the sale and thus in turn enable him to carry out his agreement with $X$. The reason that estoppel was refused was that $S$, at the time of the making of the contract, had no intent or expectation that $B$ would change his position by reselling the goods. These two illustrations serve to show that the courts are prone to insist on this element being present.

The fifth element does not present any particular difficulties :

"The conduct must be relied upon by the other party, and thus relying, he must be led to act upon it."

In other words, there must be a bona fide reliance on the validity of the contract, and it must be clear that the change of position must have resulted from such reliance and that it was not caused by extraneous circumstances. Thus where $S$ sold fruit to $B$ by an enforceable oral contract and $S$, relying on this contract, neglected to pick the fruit so that an unforeseen frost killed it, it was held that there was no estoppel, for if it had not been for the frost the contract would have been performed. Hence the change in position was not occasioned by any conduct of $B$ 's but by extraneous circumstances. ${ }^{75}$

Lastly the sixth element:

"He must in fact act upon it in such a manner as to change his position for the worse; in other words, he must

${ }^{73}$ Long et al. v. Long et al., I62 Cal. 427, 122 Pac. I077 (1912). This should be considered a border line case. The court could just as well have decided the other way. The position of the court assumes a colossal stupidity and lack of observation on the part of $B$.

${ }^{7 *}$ In Cincinnati Distributing Co. v. Sherwood and Sherwood Commercial Co., 270 Fed. 82 , at 83 (C. C. A. gth, I92I), it was said: "It is true that a contract may be within the Statute of Frauds, yet if the conduct of the party who relies upon the statute has been such as to raise an equity outside of and independent of the contract, he may be estopped to make that defence."

${ }^{\pi}$ In Stowe v. Fay Fruit Co., 90 Cal. App. 421 at 427, 265 Pac. Io42, at 1045 (I928) the court said: "The freeze of January Igth which caused all the trouble was a circumstance, of course, utterly apart from the acts of either of the parties." 
so act that he would suffer a loss if he were compelled to surrender, to forego or alter what he has done by reason of the first party being permitted to repudiate his conduct and to assert rights inconsistent with it."

This means that an actual loss must occur and such loss must be sufficiently pleaded. Mere change of position is not enough. The case of Standing $v$. Morosco is illustrative. ${ }^{76} A$, an actor, was induced by $B$ to give up his employment in New York and act for $B$ in Los Angeles. The oral contract for employment was for more than one year so that it was within the statute. $A$ gave up his position in New York, sold his furniture and moved with his wife to Los Angeles. Within two and a half months $B$ dismissed him. It was held that $B$ was not estopped to deny the oral contract for there was no actual damage shown. For aught the court knew, $A$ 's term of employment in New York may have been almost over, he might have sold his furniture at a profit, and settling in Los Angeles may have been highly beneficial. For some reason, quite inexplicable, many courts do not seem to regard entering into a binding written contract on the faith of an unenforceable collateral agreement as sufficient damage so as to enforce the latter. A Nevada court refused to raise estoppel in the following case: $A$ entered into a written agreement with $B$ for the lease of land for a period of five years. Along with that was a collateral oral agreement that $B$ should provide $A$ with forty horses every year to till the land. The second year $B$ refused to go through with this agreement. $A$ on his own initiative obtained fourteen horses, the most that he could get, but this number was insufficient to do the work and he suffered great loss. When he brought suit the court, in an unconvincing opinion, refused to allow estoppel. ${ }^{77}$ It seems obvious that $A$ would never have entered into a legally binding agreement to lease without the oral agreement so necessary to the value of the former, so that the case is somewhat dubious.

${ }^{70} 43$ Cal. App. 244, 184 Pac. 954 (1919).

7 Nehls et al. v. Williams Stock Farming Co., supra note 47. See also Robbins v. Winters et al., supra note 52 . However, in both cases redress would probably have been denied anyway for the courts refused to find the fact to base estoppel on. See supra page 454 et seq. 
It is not contended that in every case where estoppel has been set up against the Statute of Frauds, all the above mentioned elements are present. Some courts are more lenient than others, and in many cases a point will be stretched if a too rigid insistence might work injustice. But to insure recognition of the plea of estoppel, every element should be properly presented in the pleadings and proof.

\section{CONCLUSION}

In summing up, what deductions must be drawn from the cases? The most noticeable is the gradual change from a rigid insistence on the letter of the law to the broader ground of insistence on the true spirit of the law, the protection of innocent parties in their legitimate rights. For this purpose the doctrine of estoppel is the most powerful of all weapons and, metaphorically speaking, one that will temper the wind of the Statute of Frauds to the shorn lamb whether plaintiff or defendant. The underlying motif is a desire to extend this doctrine, but it is as yet not fully developed, so that two courts are liable to reach diametrically opposite results by varying interpretations of the same principle. Even when estopped is permitted, the very adjudication of the matter, though it may favor the innocent party, is cumbersome, laborious and expensive. As has been many times suggested, it might be well to repeal the statute, or at least sections four and seventeen, but in view of the immobility of most legislatures when it comes to repealing a law, such a solution is too much to hope for. However, it is barely possible that some sort of a compromise agreement might be reached. For instance, this compromise suggests itself: It would be possible to revise the statutes to cover in unambiguous terms all those contracts and claims that, from their importance or from the distant time of their ultimate performance, justify memoranda to record their existence. This is precisely what the present statute attempts to do. But in this plan the lack of such a memorandum would not be conclusive. In a preliminary hearing if it were decided by the judge that the contract was without the statute 
the trial would proceed as heretofore. If it was decided that the contract was within the statute and, contrary to present usage, the contract should be interpreted strictly, the plaintiff must prove beyond a reasonable doubt that such a contract did exist, instead of proving it by the preponderance of the evidence. In other words, he would have precisely the same burden of proof that the state has in a criminal case. Of course it is impossible to know how such a plan would work in actual practice, but it seems that anything would be better than the present hopeless jumble of contradictory cases that interpret the Statute of Frauds. 